\title{
Effects of Tomato Pomace Composts on Yield and Quality of Processing Tomato (Lycopersicon esculentum Mill.)
}

\author{
Ioannis ROUSSIS, Ioanna KAKABOUKI, Antigolena FOLINA, Aristidis KONSTANTAS, Ilias TRAVLOS, \\ Dimitrios BILALIS*
}

Agricultural University of Athens, School of Plant Sciences, Department of Crop Science, Laboratory of Agronomy, 75 Iera Odos Str., 11855 Athens, Greece.

*corresponding author: bilalisdimitrios@gmail.com

BulletinUASVM Horticulture 76(2) / 2019

Print ISSN 1843-5254, Electronic ISSN 1843-5394

DOI:10.15835/buasvmcn-hort: 2019.0019

\begin{abstract}
Organic farming encourages the use of organic waste materials as substitutes for chemical fertilizers. Tomato pomace presents an alternative to inorganic fertilizer. A field experiment was carried out to evaluate the influence of tomato pomace composts and nitrogen fertilization on agronomic and quality parameters of the processing tomato. The experiment was laid out in a randomized complete block design with three replications and five fertilization treatments (untreated, nitrogen fertilizer, tomato pomace with biocyclic humus soil, tomato pomace with manure and tomato pomace with plant residues). The results showed that the highest average fruit weight and fruit yield (163.4 t/ha) were found in plots subjected to nitrogen fertilization, while the highest total soluble solids content ( $4.29^{\circ} \mathrm{Brix}$ ), and $L^{*}$ and $a^{*}$ colour parameters, important quality parameters to processing tomato industry, were obtained through the application of tomato pomace mixed with biocyclic humus soil making organic tomatoes suitable for processing tomato industry.
\end{abstract}

Keywords: Heinz $3402 \mathrm{~F}_{1}$, surface colour, tomato pomace compost, total soluble solids

\section{Introduction}

The management of processing waste constitutes a significant issue facing the food industry. Within the European Union, the food sector produces approximately 250 million tons of by-products and waste per year, of which $10 \%$ remain after the fruit and vegetable processing (Fava et al., 2015). Moreover, 30-50\% of those byproducts and waste come from fruit and vegetable juice production (Kasapidou et al., 2014). The global food production and thereby the amount of food waste is expected to rise, requiring an increased attention. Currently, the application of waste streams partially includes the use as feed for livestock, plant fertilizer, composting, biogas material, or as a source of pectic polysaccharides or general dietary fiber, however; a large part of them are still incinerated or landfilled. As a result, they do not produce value for farmers, but result in a loss of billions of euros in waste management and cause environmental pollution (Mirabella et al., 2014).

Tomato (Lycopersicon esculentum Mill.) is one of the most widely cultivated crops with a world production of over 182 million tons in 2017 (FAOSTAT, 2019). Significant amounts of tomato are processed yearly to produce tomato juice, paste, purée, ketchup, sauce, and salsa, resulting in the generation of large quantities of a by-product, known as tomato pomace (Del Valle et al., 2006). Tomato pomace represents, at most, $5-10 \%$ of the fruit weight and is composed of around 33\% 
seed, $27 \%$ skin, and 40\% pulp (Kaur et al., 2008). Tomato pomace comprises $15.4-23,7 \%$ total protein, $25.4-50.0 \%$ fiber, $5.4-20.5 \%$ total fat, and 4.4-6.8\% mineral content on a dry matter basis. Due to its high protein content, this by-product represents an important fodder for livestock (Weiss et al., 1997).

Tomato pomace also presents an alternative to inorganic fertilizer. It is possible to use tomato pomace as a soil amendment because of its high organic matter and low toxic element content. Risks of plant pathogen dissemination and phytotoxicity hazards are eliminated when an effective sanitation of tomato waste is achieved through a composting process before the amendment to soil (Avgelis and Manios, 1989). Composting can suppress pathogens and stabilize organic matter because of the higher temperatures and the growth of aerobic microorganisms. According to the literature, a $\mathrm{C} / \mathrm{N}$ ratio of $20-30$ is recommended for digested materials (Sheets et al., 2015). Tomato pomace contains a high nitrogen concentration and has $\mathrm{C} / \mathrm{N}$ ratio of about 11 (Van Horn, 1995). Therefore, tomato pomace should be co-composted with dry and carbon rich bulking agents to adjust this $\mathrm{C} / \mathrm{N}$ ratio. Several additions have been successfully applied to balance the initial $\mathrm{C} / \mathrm{N}$ ratio, such as wheat straw and separated dairy manures (Kulcu, 2014) and cattle manure and sawdust (Kalamdhad et al., 2009). Fertilizer quality and profits of compost obtained from tomato pomace can be further improved by supplementing them with humic substances that are beneficial to plants. Humic substances can increase plant growth or even make a crop less sensitive to stressful conditions by several modes of action, such as activation of numerous plant metabolism pathways, stimulation of microbial activity and enhanced production of growth regulators in plants (Ertani et al., 2013).

Sustainable agriculture encourages the use of waste materials as substitutes for chemical fertilizers. This may be an effective way to use the high volumes of waste organic materials from tomato processing and is therefore of potentially significant environmental value. The objective of this study was to evaluate the influence of tomato pomace composts and nitrogen fertilization on agronomic and quality parameters of the processing tomato.

\section{Materials and methods}

A field experiment was carried out in the organic experimental field of Agricultural University of Athens (Latitude: $37^{\circ} 59^{\prime} \mathrm{N}$, Longitude: $23^{\circ} 42^{\prime}$ E, Altitude: $29 \mathrm{~m}$ above sea level) from May until August 2019. The soil was a clay loam $(29.8 \%$ clay, $34.3 \%$ silt and $35.9 \%$ sand) with $\mathrm{pH}(1: 1$ $\left.\mathrm{H}_{2} \mathrm{O}\right) 7.21$, nitrate-nitrogen $\left(\mathrm{NO}_{3}-\mathrm{N}\right) 11.2 \mathrm{mg} \mathrm{kg}^{-1}$ soil, available phosphorus (P) $52 \mathrm{mg} \mathrm{kg}^{-1}$ soil, available potassium (K) $33.7 \mathrm{mg} \mathrm{kg}^{-1}$ soil, $16.94 \%$ $\mathrm{CaCO}_{3}$ and $1.57 \%$ organic matter. Weather data (mean monthly temperature and precipitation) during the growing period were obtained from the weather station of Agricultural University of Athens and are shown in Figure 1. The mean

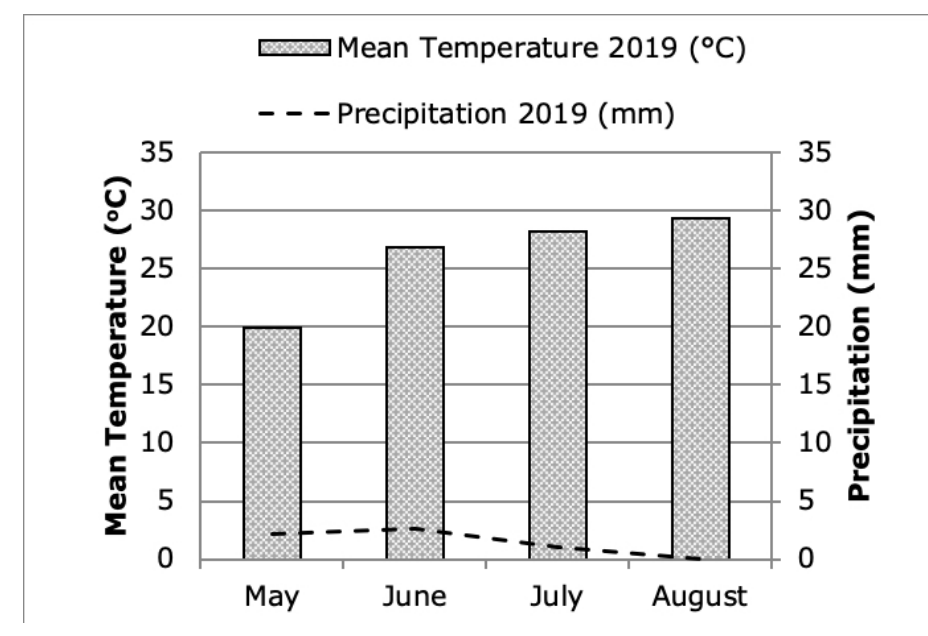

Figure 1. Weather data (mean monthly air temperature and precipitation) during the growing season (May-August, 2019) 
monthly temperature and total rainfall during the growing period were $26.1^{\circ} \mathrm{C}$ and $5.8 \mathrm{~mm}$, respectively.

The experiment was set up on an area of 187 $\mathrm{m}^{2}$ according to a randomized complete block design (RCBD), with three replications and five fertilization treatments: control (untreated), tomato pomace with biocyclic humus soil [50\% tomato pomace $+50 \%$ biocyclic humus soil (Biocyclic Park, Kalamata, Greece)] at a rate of $2000 \mathrm{~kg} \mathrm{ha}^{-1}$, tomato pomace with manure [50\% tomato pomace $+50 \%$, tomato pomace with farmyard manure (solid, $1.53 \% \mathrm{~N}$ )] at a rate of 2000 $\mathrm{kg} \mathrm{ha}^{-1}$, tomato pomace with plant residues [50\% tomato pomace $+50 \%$ plant residues $(50 \%$ wheat straw $+50 \%$ maize straw)] at a rate of $2000 \mathrm{~kg}$ ha $^{-1}$, and inorganic nitrogen fertilizer (Nutrimore Winner 40-0-0+14.5 $\mathrm{SO}_{3}$, Gavriel Ltd.) at a rate of $250 \mathrm{~kg} \mathrm{ha}^{-1}$. The characteristics of tomato pomace composts used as soil amendments are shown in Table 1.

The plot size was $9 \mathrm{~m}^{2}(3 \times 3 \mathrm{~m})$. There was a space of $0.5 \mathrm{~m}$ between plots and $1 \mathrm{~m}$ between replications. Soil was prepared by ploughing at a depth of about $25 \mathrm{~cm}$. One day before transplanting, the fertilizers were applied by hand to the soil surface and then harrowed in. Transplanting of tomato seedlings into the field was done on 2 May 2019. Tomato seedlings (Lycopersicon esculentum Mill. cv. Heinz $3402 \mathrm{~F}_{1}$ ) were transplanted by hand $50 \mathrm{~cm}$ between rows and $30 \mathrm{~cm}$ between plants per row. A drip irrigation system was also set up on the field. The total quantity of water applied during the cultivation periods was $846 \mathrm{~mm}$. Throughout the experimental period, there was no incidence of pest or disease on processing tomato crop. Finally, weeds were controlled by hand hoeing when it was necessary.
Tomato fruits were harvested at 118 days after transplanting (DAT). Fruit number per plant, average fruit weight, fruit diameter as well as fruit yield were determined by using five randomly selected plants from each plot. Fruit diameter (mm) was measured with a Starrett EC799A-6/150 electronic digital caliper (L.S. Starrett Co., Athol, MA, USA) having an accuracy of $0.02 \mathrm{~mm}$.

The qualitive parameters were assessed using five fruits per plant from three randomly selected plants from each plot. Fruit skin colour measurements were performed using a Minolta CR-300 tristimulus colorimeter (Konica Minolta, Inc., Sakai, Osaka 590-8551, Japan). Colour was recorded according to the CIE- $L^{*} a^{*} b^{*}$ colour space system. Two measurements were made at the equatorial region of the pericarp of each fruit and the mean values were calculated. Colour index (CI) was calculated using the following formula (Jimenez-Cuesta et al., 1981):

$$
\mathrm{CI}=1000 \mathrm{a}^{*} \mathrm{~L}^{*-1} \mathrm{~b}^{*-1}
$$

Fruit firmness was measured at the equatorial region by recording the force required to insert a $6.3 \mathrm{~mm}$-diameter conical needle to a depth of $0.6 \mathrm{~cm}$ in the fruit using a Chatillon DFIS 10 penetrometer connected to a Chatillon TCM 201M motorized force test stand (John Chatillon and Sons, Inc., Greensboro, NC 27425, USA) and moving at a constant speed of $200 \mathrm{~mm} \mathrm{~min}^{-1}$.

Total soluble solids (TSS) content was measured at $20^{\circ} \mathrm{C}$ with a Schmidt \& Haensch HR32B hand- held refractometer (Schmid \& Haensch GmbH \& Co., 13403 Berlin, Germany) having a sensitivity of $0.2^{\circ}$ Brix. Titratable acidity (TA) was determined by titrating $10 \mathrm{ml}$ of diluted tomato pulp with $\mathrm{N} / 50 \mathrm{NaOH}$ using $1 \%$ phenolphthalein indicator.

Table 1. Characteristics of tomato pomace composts used as soil amendments

\begin{tabular}{|c|c|c|c|c|c|c|c|}
\hline & $\begin{array}{c}\text { Organic } \\
\text { Matter (\%) }\end{array}$ & $\begin{array}{c}\mathrm{EC}(\mathrm{mS} / \\
\mathrm{cm})\end{array}$ & pH & $\begin{array}{l}\mathrm{N} \text { total } \\
(\%)\end{array}$ & $\begin{array}{c}\text { P Olsen } \\
\left(\mathrm{mg} \mathrm{kg}^{-1}\right)\end{array}$ & $\begin{array}{c}\mathrm{K} \\
\left(\mathrm{mg} \mathrm{kg}^{-1}\right) \\
\end{array}$ & $\begin{array}{c}\mathrm{Mg} \\
\left(\mathrm{mg} \mathrm{kg}^{-1}\right) \\
\end{array}$ \\
\hline $\begin{array}{l}\text { Tomato pomace with } \\
\text { biocyclic humus soil }\end{array}$ & 51 & 1.71 & 7.28 & 2.78 & 14 & 31 & 0.78 \\
\hline $\begin{array}{l}\text { Tomato pomace with } \\
\text { manure }\end{array}$ & 44 & 1.68 & 7.41 & 3.10 & 21 & 33 & 0.66 \\
\hline $\begin{array}{l}\text { Tomato pomace with } \\
\text { plant residues }\end{array}$ & 45 & 1.74 & 7.36 & 2.88 & 16 & 31 & 0.32 \\
\hline
\end{tabular}


The experimental data were analyzed using the SigmaPlot 12 statistical software (Systat Software Inc., San Jose, CA, USA) according to the randomized complete block design (RCBD). Values were compared by analysis of variance (ANOVA) and differences between means were separated using the Least Significant Difference (LSD) test. Correlation analyses were used to describe the relationships between yield and quality characteristics using Pearson's correlation. All comparisons were made at the $5 \%$ level of significance $(p \leq 0.05)$.

\section{Results and discussion}

The fruit number per plant is presented in Figure 2a. The effect of different fertilization regimes was found to be statistically significant $(F=8.74, p=0.017)$. In particular, the highest number of fruits per plant (58.3) was achieved in plots fertilized with inorganic fertilizer, while the lowest value (47.8) was found in the unfertilized (control) treatment. The results obtained concur with earlier findings of Patil et al. (2004) and Bilalis et al. (2018).

The average fruit weight differed among the fertilization treatments $(F=6.10, p=0.036)$. with highest value $(62.2 \mathrm{~g})$ obtained in the inorganic treatment followed by tomato pomace mixed with biocyclic humus soil (52.6 g) and tomato pomace mixed with manure (53.7). The lowest value (38.7) was observed in untreated plants (Fig. 2b). In an experiment conducted under tropical andosol soil conditions, it was found that the weight of tomato fruits was not influenced by fertilization regimes or cultivars (Tonfack et al., 2009). The differences among those findings could be related to the variation in cultivars, soil type, temperature and rainfall during the growing periods of those experiments.
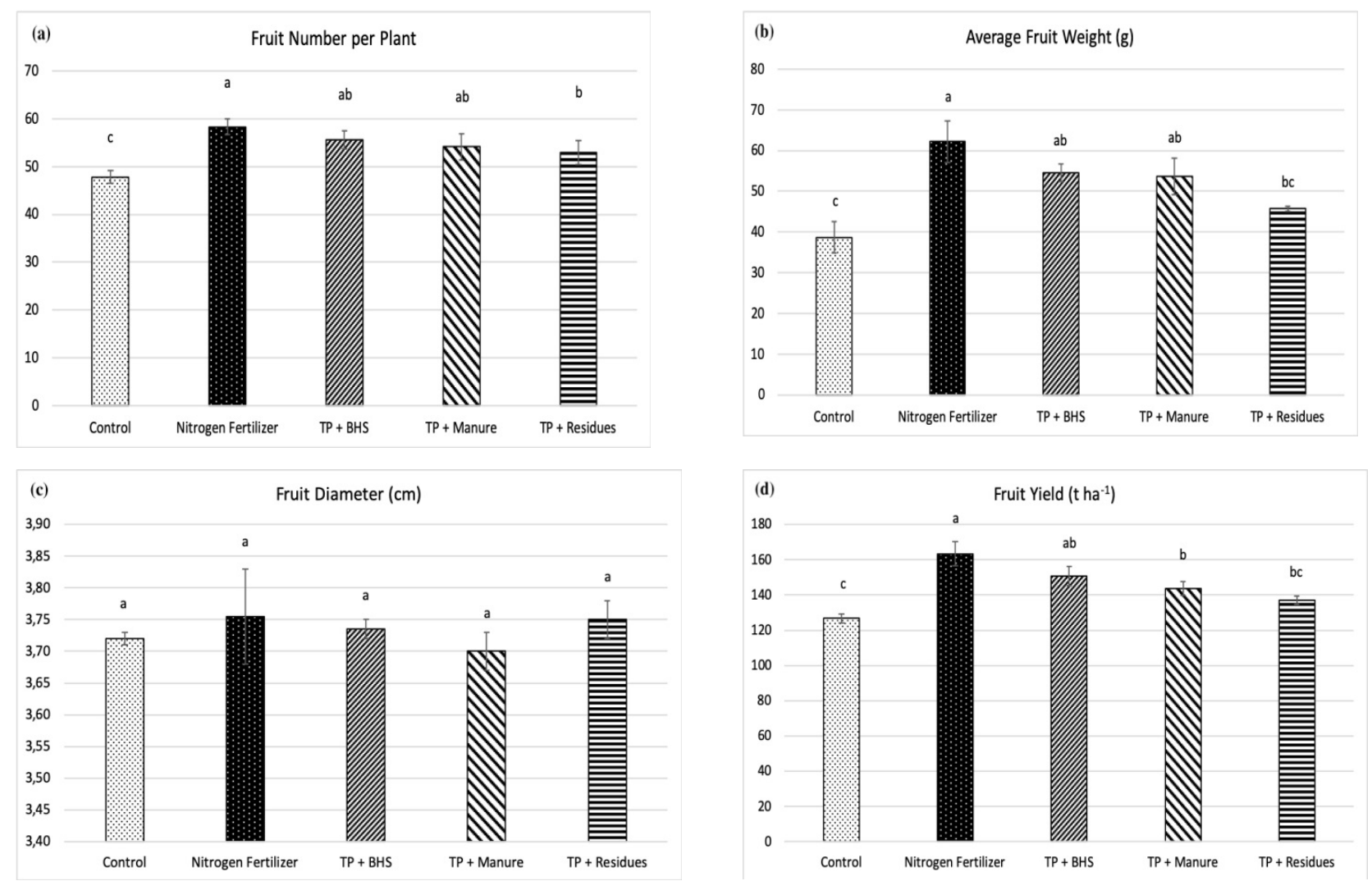

Figure 2. Effects of fertilization [control, inorganic nitrogen fertilizer, tomato pomace mixed with biocyclic humus soil (TP + BHS), tomato pomace mixed with manure (TP + Manure) and tomato pomace mixed with plant residues (TP + Residues)] on a) fruit number per plant, b) average fruit yield, c) fruit diameter and d) fruit yield. Vertical lines represent standard mean errors. Different low-case letters denote statistically significant differences according to the $L S D$ test $(\mathrm{p} \leq 0.05)$. 
Concerning the fruit diameter, there were no significant differences among fertilization treatments $(F=0.32, p=0.849)$. Despite that, the highest fruit diameter $(3.76 \mathrm{~cm})$ was observed in plants fertilized with the inorganic nitrogen fertilizer (Fig. 2c). This characteristic is dependent on cultivar genotype (Bilalis et al., 2018).

The analysis of variance revealed that fruityield was actually affected by the different fertilization regimes $(F=9.45, p=0.014)$. Specifically, the highest yield (163.4 $\mathrm{t} \mathrm{ha}^{-1}$ ) was found in plots fertilized with inorganic nitrogen fertilizer followed by tomato pomace mixed with biocyclic humus soil (150.7 t ha $^{-1}$ ) (Fig. 2d). Tomato plants fertilized with inorganic fertilizers produced higher fruit yield, since inorganic fertilizers contained soluble inorganic nitrogen with quick availability for plants (Murmu et al., 2013; Ronga et al., 2017). Fruit yield had a significant and positive correlation with fruit number ( $r=0.74, p=0.013)$ and average fruit weight $(r=0.97, p<0.001)$.

Fruit firmness is one of the most important quality traits of tomato processed in the canning industry, especially, of canned whole tomatoes. Fruit firmness, was not affected by fertilization $(F=1.82, p=0.263)$; however, the highest value (4.53 $\mathrm{kg} \mathrm{cm}^{-2}$ ) was obtained in untreated plots, while the lowest value $\left(4.46 \mathrm{~kg} \mathrm{~cm}^{-2}\right)$ was found in plots treated with inorganic nitrogen fertilizer (Fig. 3a). Knee et al. (2002) reported that fruit firmness is negatively correlated with the increase of nitrogen content in fruits. A significant and positive correlation was observed between fruit firmness and average fruit weight $(r=0.73$, $p=0.016$ ).

The soluble solids are important for tomato quality and for processed concentrate as they influence sweetness, sourness and flavor
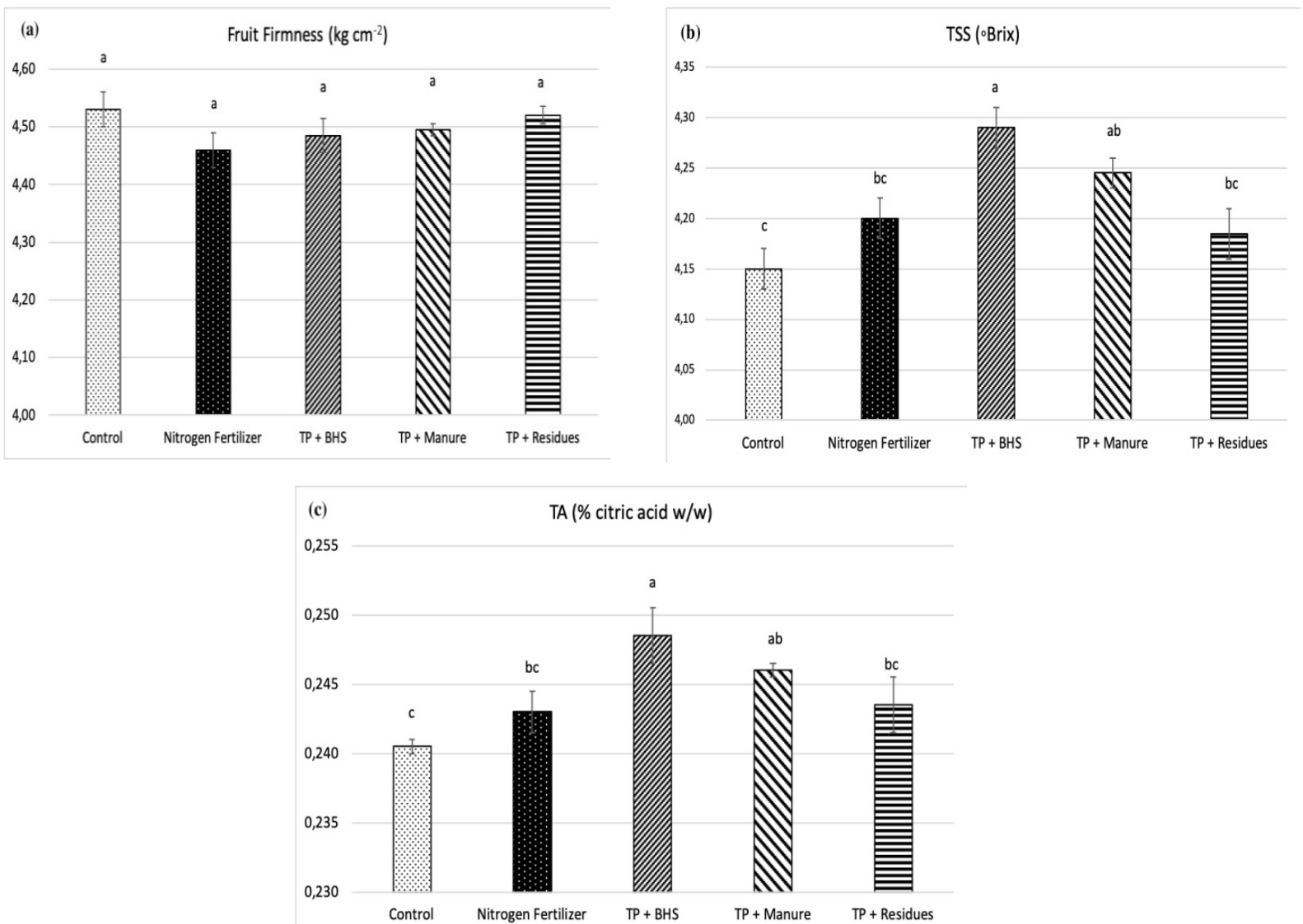

Figure 3. Effects of fertilization [control, inorganic nitrogen fertilizer, tomato pomace mixed with biocyclic humus soil (TP + BHS), tomato pomace mixed with manure (TP + Manure) and tomato pomace mixed with plant residues (TP + Residues)] on a) fruit firmness, b) total soluble solids (TSS) and c) titratable acidity (TA). Vertical

lines represent standard mean errors. Different low-case letters denote statistically significant differences according to the $L S D$ test $(\mathrm{p} \leq 0.05)$. 
intensity. Total soluble solids (TSS) is composed of a mixture of predominate sugars (65\%), acids $(13 \%)$ and other compounds (mainly amino acids, ascorbate, minerals, pectins, and phenols) which increase the colour and maturity (Beckles, 2012). According to the analysis of variance, TSS content was significantly affected by fertilization $(F=7.24, p=0.026)$ with the highest value (4.29 ${ }^{\circ}$ Brix) observed in tomatoes fertilized with tomato pomace mixed with biocyclic humus soil (Figure $3)$. These results are in line with Barrett et al. (2007) who reported that there was a higher TSS content in processing tomatoes grown organically in comparison to those chemically fertilized. In addition, humic substances, contained in biocyclic humus soil, stimulated photosynthesis, with the result that there were more assimilates for the tomato fruits which increased TSS content (Eisenbach et al., 2019).
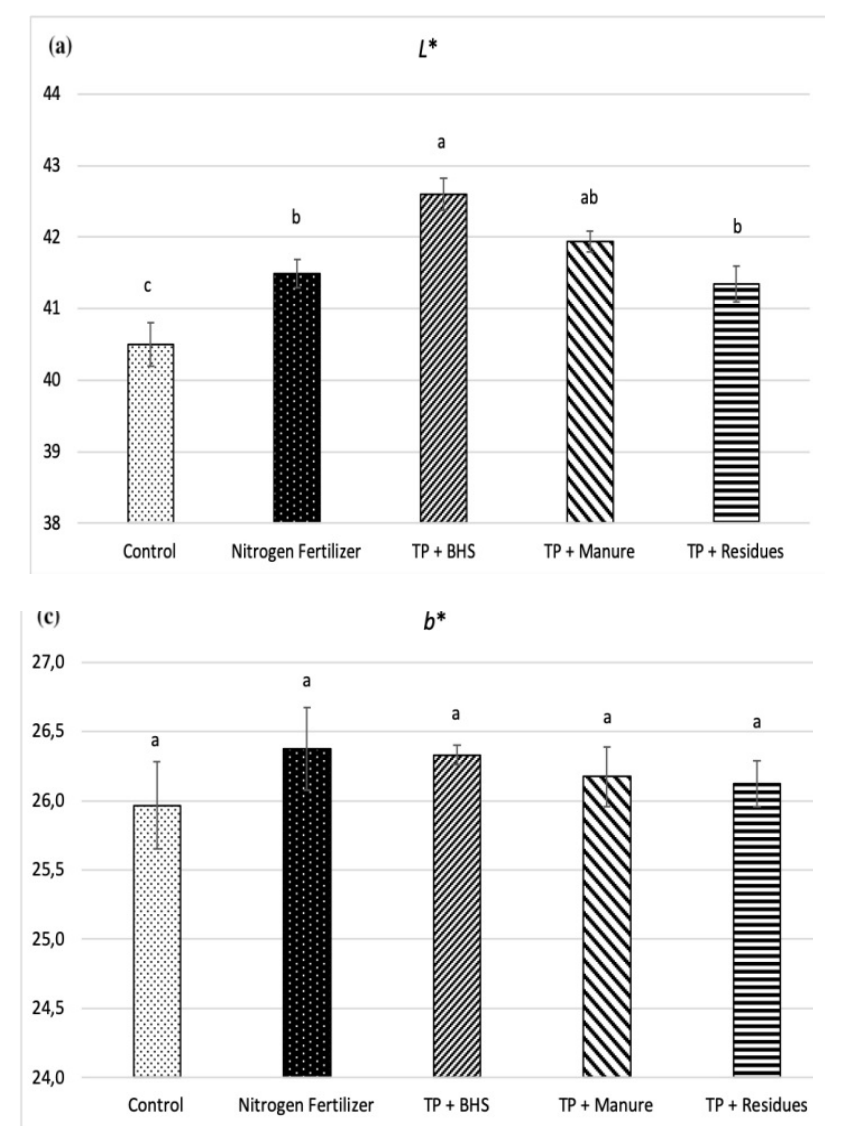

Titratable acidity is an important quality parameter contributing to the flavor of tomato products. This trait was significantly affected by different fertilization regimes $(F=4.33, p=0.041)$ with the values being $0.249 \%, 0.246 \%, 0.244 \%$, $0.243 \%$ and $0.241 \%$ citric acid $\mathrm{w} / \mathrm{w}$ for tomato pomace mixed with biocyclic humus soil, tomato pomace mixed with manure, tomato pomace mixed with plant residues, inorganic fertilizer and untreated variants, respectively (Fig. 3c). These results are in accordance with other studies which found that tomatoes grown in nitrate-dominant fertilizer solutions had significantly lower values of titratable acidity than those grown fertilized with organic fertilizers (Barrett et al., 2007; Bilalis et al., 2018).

Tomato fruit colour is one of the essential and quality characteristics of the fruit and relates primarily to the lycopene content (Garcia and
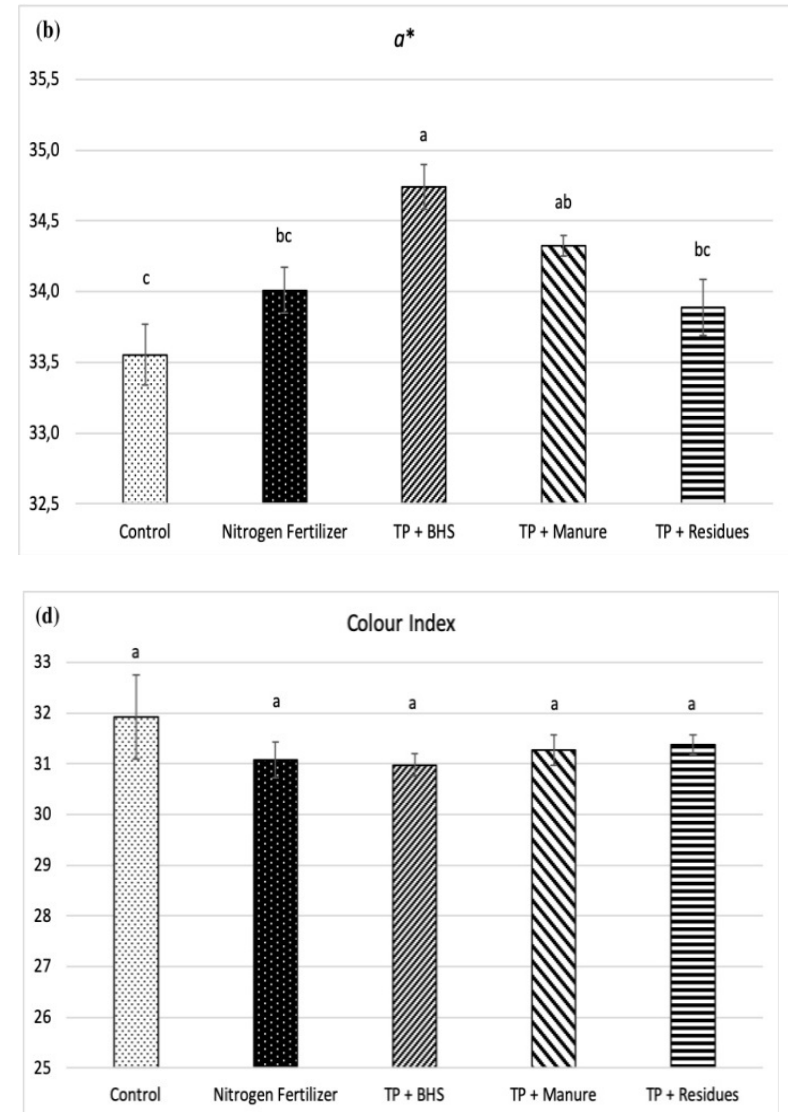

Figure 4. Effects of fertilization [control, inorganic nitrogen fertilizer, tomato pomace mixed with biocyclic humus soil (TP + BHS), tomato pomace mixed with manure (TP + Manure) and tomato pomace mixed with plant residues (TP + Residues)] on fruit surface color: a) $L$ value, b) $a$ value, c) $b$ and d) Colour Index (CI). Vertical lines represent standard mean errors. Different low-case letters denote statistically significant differences according to the $L S D$ test $(\mathrm{p} \leq 0.05)$. 
Barrett, 2006). In the present experiment, colour lightness $\left(L^{*}\right)$ was significantly influenced by the different fertilization treatments $(F=11.54$, $p=0.009$ ). The highest value (42.6) was found in tomatoes treated with tomato pomace mixed with biocyclic humus soil, indicating that the red colour of those tomatoes was lighter (Fig. 4a). A positive and significant correlation was found between lightness and total soluble solids $(r=0.87$, $p=0.021$ ). Concerning $a^{*}$ value which represents the green-red component ( $a^{*}>0$ red, $a^{*}<0$ green), it was significantly different among fertilization regimes $(F=7.07, p=0.027)$. The data showed that the tomatoes fertilized with tomato pomace mixed with biocyclic humus soil presented the highest value (34.74) (Fig. 4b). The $a^{*}$ value has the tendency to increase during ripening stage, as the red colour is the result of lycopene synthesis (Garcia and Barrett, 2006). A significant and positive correlation was found between $a^{*}$ value and total soluble solids $(\mathrm{r}=0.98, \mathrm{p}<0.001)$. The $b^{*}$ value represents the difference between blue $\left(-b^{*}\right)$ and yellow $\left(+b^{*}\right)$. This value, which has the tendency to increase from the breaker to turningstage and then to decrease until the red stage, was not affected by different fertilization treatments $(F=0.51, p=0.731)$ with the values ranging 25.97 to 26.38 (Fig. 4c). The Colour Index that presents a high correlation with the external visual colour of fruit, was also not influenced by fertilization $(F=0.69, p=0.629)$; however, the highest value (31.92) was observed in the untreated plot, while the lowest (30.97) in tomato pomace mixed with biocyclic humus soil (Fig. 4d).

\section{Conclusion}

The results of the present study indicated that the yield and quality parameters of processing tomato were significantly affected by the different fertilization regimes. The highest yield parameters were observed under nitrogen fertilization, while the highest total soluble solids content as well as $L^{*}$ and $a^{*}$ colour parameters, important quality parameters to processing tomato industry, were found in plots treated with tomato pomace mixed with biocyclic humus soil making organic tomatoes suitable for processing tomato industry. Further studies are needed in order to investigate the seasonality and cultivar effects.
Acknowledgements: This work was carried out as part of the research program: "SusTainable explOitation of toMATO proCessing industrY byproduCts (TOMATOCYCle)" funded under the RIS3 Priority Sector Support "Development of Transnational Research Projects for Small and Medium-Sized Enterprises" under the Operational Program “Western Greece 2014-2020".

\section{References}

1. Avgelis AD, Manios VI (1989). Elimination of tomato mosaic virus by composting tomato residues. Netherlands Journal of Plant Pathology, 95: 167-170.

2. Barrett DM, Weakley C, Diaz JV, Watnik M (2007). Qualitative and nutritional differences in processing tomatoes grown under commercial organic and conventional production systems. Journal of Food Science 72(9): C441-451.

3. Beckles DM (2012). Factors affecting the postharvest soluble solids and sugar content of tomato (Solanum lycopersicum L.) fruit. Postharvest Biology and Technology, 63: 129-140.

4. Bilalis D, Krokida M, Roussis I, Papastylianou P, Travlos I, Cheimona N, Dede A (2018). Effects of organic and inorganic fertilization on yield and quality of processing tomato (Lycopersicon esculentum Mill.). Folia Horticulturae, 30(2): 321-332.

5. Del Valle M, Cámara M, Torija, M-E (2006). Chemical characterization of tomato pomace. Journal of the Science of Food and Agriculture, 86(8): 1232-1236.

6. Eisenbach LD, Folina A, Zisi C, Roussis I, Tabaxi I, Papastylianou P, Kakabouki I, Efthimiadou A, Bilalis DJ (2019). Effect of Biocyclic Humus Soil on Yield and Quality Parameters of Processing Tomato (Lycopersicon esculentum Mill.). Bulletin UASVM Horticulture, 76(1): 4752.

7. Ertani A, Pizzeghello D, Baglieri A, Cadili V, Tambone F, Gennari M, Nardi S (2013). Humic-like substances from agro-industrial residues affect growth and nitrogen assimilation in maize (Zea mays L.) plantlets. Journal of Geochemical Exploration, 129: 103-111.

8. Fava F, Totaro G, Diels L, Reis M, Duarte J, Carioca OB, PoggiVaraldo HM, Ferreira BS (2015). Biowaste biorefinery in Europe: Opportunities and research \& development needs. New Biotechnology, 32: 100-108.

9. Food and Agriculture Organization of the United Nations, FAOSTAT statistics database (2019). http://www.fao.org/ faostat/en/\#data/QC Accessed 05.09.2019.

10. Garcia E, Barrett DM (2005). Evaluation of processing tomatoes from two consecutive growing seasons: quality attributes, peelability and yield. Journal of Food Processing and Preservation, 30: 20-36.

11. Jimenez-Cuesta M, Cuquerella J, Martinz-Javaga JM (1981). Determination of a color index for citrus fruits degreening. Proc. International Society of Citriculture. International Citrus Congress. 9-12 November, Tokyo, 750-753. 
12. Kalamdhad AS, Singh YK, Ali M, Khwairakpam M, Kazmi AA (2009). Rotary drum composting of vegetable waste and tree leaves. Bioresource Technology, 100: 6442-6450.

13. Kasapidou E, Sossidou E, Mitlianga P (2014). Fruit and vegetable processing by-/co-products: Can they be used as functional feed ingredients in animal nutrition to produce novel value-added products? Proceedings of the 3rd International ISEKI Food Conference ISEKI_Food 2014; Athens, Greece. 21-23 May 2014.

14. Kaur D, Wani AA, Oberoi DP, Sogi DS (2008). Effect of extraction conditions on lycopene extractions from tomato processing waste skin using response surface methodology. Food Chemistry, 108(2): 711-718.

15. Knee M (2002). Fruit Quality and Its Biological Basis. Sheffield Academic Press, Sheffield, UK.

16. Kulcu R (2014). Composting of greenhouse tomato plant residues, wheat straw, and separated dairy manure, and the effect of free air space on the process. Polish Journal of Environmental Studies, 23: 1341-1346.

17. Mirabella N, Castellani V, Sala S (2014). Current options for the valorization of food manufacturing waste: A review. Journal of Cleaner Production 65: 28-41.

18. Murmu K, Ghosh BC, Swain DK (2013). Yield and quality of tomato grown under organic and conventional nutrient management. Archives of Agronomy and Soil Science, 59(10): 1311-1321.
19. Patil MB, Mohammed RG, Ghadge PM (2004). Effect of organic and inorganic fertilizers on growth, yield and quality of tomato. Journal of Maharashtra Agricultural Universities, 29: 124-127.

20. Ronga D, Zaccardelli M, Lovelli S, Perrone D, Francia E, Milc J, Ulrici A, Pecchioni N (2017). Biomass production and dry matter partitioning of processing tomato under organic vs conventional cropping systems in a Mediterranean environment. Scientia Horticulturae, 224: 163-170.

21. Sheets JP, Yang L, Ge X, Wang Z, Li Y (2015). Beyond land application: Emerging technologies for the treatment and reuse of anaerobically digested agricultural and food waste. Waste Management 2015, 44, 94-115.

22. Tonfack LB, Bernadac A, Youmbi E, Mbouapouognigni VP, Ngueguim M, Akoa A (2009). Impact of organic and inorganic fertilizers on tomato vigor, yield and fruit composition under tropical andosol soil condition. Fruits, 64: 167-177.

23. Van Horn M (1995). Compost production and utilization: A grower's guide. Publication 2154 University of California, Division of Agriculture and Oakland and Natural Resources, CA, USA.

24. Weiss WP, Forbose DL, Koch ME (1997). Wet tomato pomace ensiled with corn plants for dairy cows. Journal of Dairy Science, 80: 2996-2900. 